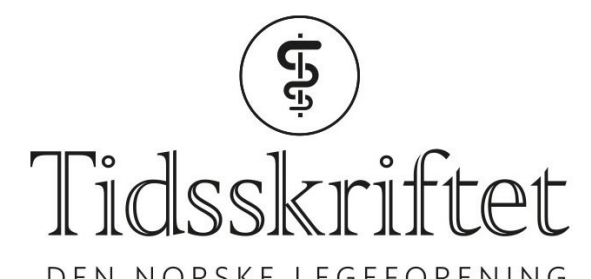

DEN NORSKE LEGEFORENING

\title{
Grunnleggende om ernæring
}

ANMELDELSER

PÉTUR BENEDIKT JÚLÍUSSON

Overlege, Barne- og ungdomsklinikken

Haukeland universitetssykehus

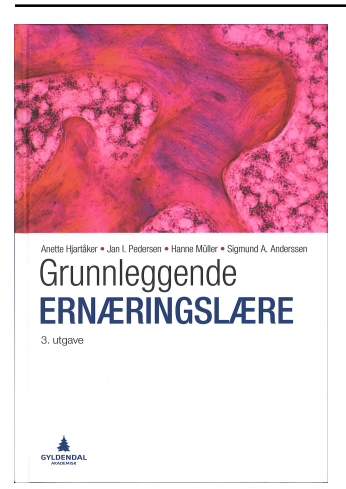

Anette Hjartåker, Jan I. Pedersen, Hanne Müller et al.

Grunnleggende ernæringslære

3. utg. 475 s, tab, ill. Oslo: Gyldendal Akademisk, 2017. Pris NOK 729

ISBN 978-82-05-49693-4

Dette er den tredje reviderte utgaven av en lærebok i grunnleggende ernæringslære, innledningsvis definert av forfatterne som «kunnskap om næringsstoffenes fordøyelse, omsetning og funksjon i en normal organisme». Hovedvekten er lagt på «samspillet mellom kosthold og fysisk aktivitet for god helse» og er rettet mot studenter i medisin, ernæring, idrettsfag, fysioterapi og fagområder innen forebyggende helse.

Her går man grundig til verks. De 16 kapitlene omfavner elementære aspekter av faget; innsamling av kostdata, oversikt over kostholdet i Norge, energiomsetningen og fordøyelsesanatomien. Videre finner man oversikt over de energigivende næringsstoffene (karbohydrater, fett, proteiner), vann og elektrolytter, vitaminer og mineralstoffer. Egne kapitler er viet kosthold og helse, fysisk aktivitet og helse samt om kosthold hos undergrupper som gravide, barn, eldre og personer med funksjonshemning eller sykdom. Avslutningsvis er det et eget kapittel om norsk ernæringspolitikk. Vekstkurver utarbeidet av WHO, Natvigs høyde- og vekttabeller samt norske anbefalinger for kosthold, ernæring og fysisk aktivitet følger som vedlegg. På nettsiden til Gyldendal kommer det frem at det sistnevnte vedlegget er feil, det riktige vedlegget er nedlastbart fra nettsiden. Et bra stikkordregister følger boken.

Med sine 475 sider er ikke boken overveldende. Språket er godt og boken lettlest, de mange 
figurene og tabellene øker også lesbarheten.

Siden studenter er målgruppen, ville sammendragsrammer til hvert kapittel ha $\emptyset \mathrm{kt} \mathrm{det}$ pedagogiske potensialet. I 2017, hvor over halvparten av den voksne befolkningen og hvert femte barn er overvektige, kunne man tenkt seg bedre gjennomgang av kroppssammensetningsmålinger samt grundigere beskrivelse av den nevroendokrinologiske styringen av energibalansen. Det hadde også vært naturlig å i større grad trekke inn pediatriske perspektiver. For eksempel er avvikende vekt ikke definert hos barn, og referanseområder for barns vekst over fem år mangler.

I tillegg til å være av stor glede for studenter av samtlige helsefag, vil boken også fungere som et godt oppslagsverk for alle som er interessert i ernæringslære. Jeg er temmelig sikker på at mange trenger å oppgradere sine kunnskaper på dette feltet. Temaet har også vært underprioritert i den medisinske utdanningen.

Publisert: 8. mai 2018. Tidsskr Nor Legeforen. DOI: 10.4045/tidsskr.18.0030

(C) Tidsskrift for Den norske legeforening 2020. Lastet ned fra tidsskriftet.no 